\title{
Effects of Electrochemical Reduction Reactions on the Biodegradation of Recalcitrant Organic Compounds (ROCs) and Bacterial Community Diversity
}

\author{
Lee, Woo Jin ${ }^{1}$, Jong Kwang Lee ${ }^{2}$, Jinwook Chung ${ }^{2}$, Yong-Ju Cho ${ }^{2}$, and Doo Hyun Park ${ }^{1 *}$ \\ ${ }^{1}$ Department of Biological Engineering, Seokyeong University, Seoul 136-704, Korea \\ ${ }^{2} R \& D$ Center, Samsung Engineering Company Ltd., Yongin 449-884, Korea
}

Received: October 14, 2009 / Revised: May 3, 2010 / Accepted: May 4, 2010

Five bacterial species, capable of degrading the recalcitrant organic compounds (ROCs) diethyleneglycol monomethylether (DGMME), 1-amino-2-propanol (APOL), 1-methyl-2pyrrolidinone (NMP), diethyleneglycol monoethylether (DGMEE), tetraethyleneglycol (TEG), and tetrahydrothiophene 1,1-dioxide (sulfolane), were isolated from an enrichment culture. Cupriavidus sp. catabolized $93.5 \pm 1.7 \mathrm{mg} / \mathrm{l}$ of TEG, 99.3 $\pm 1.2 \mathrm{mg} / \mathrm{l}$ of DGMME, 96.1 $\pm 1.6 \mathrm{mg} / \mathrm{l}$ of APOL, and $99.5 \pm 0.5 \mathrm{mg} / \mathrm{l}$ of NMP in 3 days. Acineobacter sp. catabolized $100 \mathrm{mg} / \mathrm{l}$ of DGMME, $99.9 \pm 0.1 \mathrm{mg} / \mathrm{l} \mathrm{of} \mathrm{NMP}$, and $100 \mathrm{mg} / \mathrm{l}$ of DGMEE in 3 days. Pseudomonas sp.3 catabolized $95.7 \pm 1.2 \mathrm{mg} / \mathrm{l}$ of $\mathrm{APOL}$ and $99.8 \pm 0.3 \mathrm{mg} / \mathrm{l}$ of $\mathrm{NMP}$. Paracoccus sp. catabolized $98.3 \pm 0.6 \mathrm{mg} / \mathrm{l}$ of DGMME and $98.3 \pm 1.0 \mathrm{mg} / \mathrm{l}$ of DGMEE in 3 days. A maximum $43 \pm 2.0 \mathrm{mg} / \mathrm{l}$ of sulfolane was catabolized by Paracoccus sp. in 3 days. When a mixed culture composed of the five bacterial species was applied to real wastewater containing DGMME, APOL, NMP, DGMEE, or TEG, 92 99\% of each individual ROC was catabolized within 3 days. However, at least 9 days were required for the complete mineralization of sulfolane. Bacterial community diversity, analyzed on the basis of the TGGE pattern of $16 \mathrm{~S}$ rDNA extracted from viable cells, was found to be significantly reduced in a conventional bioreactor after 6 days of incubation. However, biodiversity was maintained after 12 days of incubation in an electrochemical bioreactor. In conclusion, the electrochemical reduction reaction enhanced the diversity of the bacterial community and actively catabolized sulfolane.

Keywords: Electrochemical reduction, xenobiotics, TGGE, ethyleneglycol, pyrrolidinone, thiophene

*Corresponding author

Phone: +82-2-940-7190; Fax: +82-2-919-0345;

E-mail: baakdoo@skuniv.ac.kr
An enormous quantity and variety of recalcitrant organic compounds (ROCs) are utilized by industry. As a result of their persistence, toxicity, and transformation into hazardous metabolites, ROCs are known to be the cause of considerable environmental pollution and human health problems [5]. Some ROCs are degraded, or mineralized, by a variety of heterotrophic microorganisms. However, the resulting biodegradation process can be much slower than the biodegradation process of the biologically produced organic compounds [4]. This low biodegradability may be attributable to the incapability of the microorganisms to effectively metabolize ROCs with uncommon chemical structures or properties, within natural environments. Such compounds, which are alien to existing enzyme systems, are referred to as xenobiotics [44]. The adaptation of microorganisms for the biodegradation of xenobiotics is a phenomenon that can be elicited in mixed microbial communities and in individual microbial lineages. Virtually no biodegradation of ROCs occurs immediately after the first exposure of the microbial community to these compounds. Rather, mineralization begins after a period ranging from hours to months $[2,8,31,40]$. The sufficient or optimal time required for bacterial adaptation upon exposure to xenobiotic substrates may be a factor in determining the degradation efficiency of contaminants in the natural environment $[3,43,47]$. The duration of the acclimation period, necessary to induce a bacterial community or population to degrade measurable xenobiotic substrates based upon relevant adaptation mechanisms, has been theorized in a range from minutes to, in some cases, years $[1,46]$. The specific factors required for the induction of degradative genes include nutritional elements for the promotion of cell growth, and solid support for the conjugal transfer of plasmids may make it possible to accelerate the adaptation process [17, 30, 33, 34, 41, 44]. 
The classic batch, or continuous enrichment technique, has been previously applied to facilitate the adaptation of microorganisms to target xenobiotics $[12,15]$. A variety of bacterial species have been isolated and characterized that effectively degrade the xenobiotic compounds discharged in a variety of industrial fields [7, 11, 13, 22].

In this study, a number of xenobiotic-degrading bacteria were isolated from an enrichment culture system using six ROCs [diethyleneglycol monomethylether (DGMME), 1-amino-2-propanol (APOL), 1-methyl-2-pyrrolidinone (NMP), diethyleneglycol monoethylether (DGMEE), tetraethyleneglycol (TEG), and tetrahydrothiophene 1,1-dioxide (sulfolane)] as sole carbon sources. Five bacterial strains were ultimately selected on the basis of their ability to degrade individual ROCs. In order to estimate the effects of electrochemical reduction reactions on the biodegradation of the ROCs, five bacterial mixtures were cultivated in artificial wastewater containing a mixture of ROCs. ROC degradation efficiency and bacterial community diversity were then chemically, microbiologically, and genetically analyzed.

\section{Materials ANd Methods}

\section{Chemicals}

In this study, DGMME (bp, $195^{\circ} \mathrm{C}$ ), TEG (bp, $\left.314^{\circ} \mathrm{C}\right)$, DGMEE (bp, $194^{\circ} \mathrm{C}$ ), APOL (bp, $158 \sim 162^{\circ} \mathrm{C}$ ), NMP (bp, 78 79 ${ }^{\circ} \mathrm{C}$ ), sulfolane (bp, $104^{\circ} \mathrm{C}$ ), and other chemicals utilized for isolation of ROC-degrading bacteria, were purchased from the Korean branch of Sigma-Aldrich (Yongin, Korea). All of the ROCs were water soluble and not volatile at a $30^{\circ} \mathrm{C}$ incubation temperature, based on their having boiling points (bp) between $78^{\circ} \mathrm{C}$ and $314^{\circ} \mathrm{C}$.

\section{Wastewaters}

Two kinds of wastewater (A and B) were obtained from an electronics company ( $\mathrm{S}$ Electronics) located in Tangjeong-myon, Asan, Chungcheong-namdo, Korea. The $\mathrm{pH}$ of wastewater A and $\mathrm{B}$ was 8.5 and 10.5, respectively, and was subsequently adjusted to be within the range of $7.0 \pm 0.2$ through the application of $0.1 \mathrm{~N} \mathrm{HCl}$. Wastewater A contained 1,250 mg/l of DGMME and wastewater B contained $36 \mathrm{mg} / \mathrm{l}$ of TEG, $166 \mathrm{mg} / \mathrm{l}$ of DGMEE, $75 \mathrm{mg} / \mathrm{l}$ of APOL, $532 \mathrm{mg} / \mathrm{l}$ of NMP, and $238 \mathrm{mg} / \mathrm{l}$ of sulfolane, all measurements being determined after the adjustment of the $\mathrm{pH}$ levels. One $\mathrm{g} / \mathrm{l}$ of $\mathrm{NH}_{4} \mathrm{Cl}, 1 \mathrm{~g} / \mathrm{l}$ of $\mathrm{KH}_{2} \mathrm{PO}_{4}$, and $1 \mathrm{ml} / \mathrm{l}$ of trace mineral stock solution were added to the wastewaters as the inorganic nutrients for bacterial growth. The trace mineral stock solution contained $0.01 \mathrm{~g} / \mathrm{l}$ $\mathrm{MnSO}_{4}, 0.01 \mathrm{~g} / \mathrm{l}$ of $\mathrm{MgSO}_{4}, 0.01 \mathrm{~g} / \mathrm{l}$ of $\mathrm{CaCl}_{2}, 0.002 \mathrm{~g} / \mathrm{l}$ of $\mathrm{NiCl}_{2}$, $0.002 \mathrm{~g} / \mathrm{l}$ of $\mathrm{CoCl}_{2}, 0.002 \mathrm{~g} / \mathrm{l}$ of $\mathrm{SeSO}_{4}, 0.002 \mathrm{~g} / \mathrm{l}$ of $\mathrm{WSO}_{4}, 0.002 \mathrm{~g} / \mathrm{l}$ of $\mathrm{ZnSO}_{4}, 0.002 \mathrm{~g} / \mathrm{l}$ of $\mathrm{Al}_{2}\left(\mathrm{SO}_{4}\right)_{3}, 0.0001 \mathrm{~g} / \mathrm{l}$ of $\mathrm{TiCl}_{3}, 0.002 \mathrm{~g} / \mathrm{l}$ of $\mathrm{MoSO}_{4}$, and $10 \mathrm{mM}$ EDTA [23].

\section{Isolation of ROC-Degrading Bacteria}

Bacterial species were isolated from the enrichment culture of a bacterial community grown through the use of a variety of xenobiotic compounds. The nitrogen-phosphorus basal medium for the enrichment culture was composed of $2 \mathrm{~g} / \mathrm{l}$ of $\mathrm{NH}_{4} \mathrm{Cl}, 2 \mathrm{~g} / \mathrm{l}$ of
$\mathrm{KH}_{2} \mathrm{PO}_{4}, 2 \mathrm{~g} / 1 \mathrm{NaNO}_{3}$, and $2 \mathrm{ml} / 1$ of trace mineral stock solution. The bacterial sources used for the enrichment culture were city soils that have been contaminated with petroleum (Gangwha-Gun in Incheon Metrocity; Yeocheon City in Cheonra-namdo; and Ulsan City in Kyungsang-bukdo), seashore soils contaminated with petroleum (Gangwha Island in Kyunggi-do; and Namhae Island in Kyunsangnamdo), and agricultural soil from farm fields cultivated using pesticides and insecticides (Yongin City; Pocheon City; and Incheon metropolitan city in Kyunggi-do). A mixture (wet weight, $100 \mathrm{~g}$ ) of the various soils obtained from all the different locations was suspended in $500 \mathrm{ml}$ of a nitrogen-phosphorus basal medium. A mixture of volatile xenobiotics, benzene $[10 \%(\mathrm{v} / \mathrm{v})]$, toluene $[10 \%$ $(\mathrm{v} / \mathrm{v})]$, ethylbenzene $[10 \%(\mathrm{v} / \mathrm{v})]$, xylene $[10 \%(\mathrm{v} / \mathrm{v})]$, thiophenes $[5 \%(\mathrm{v} / \mathrm{v})]$, and crude petroleum [55\% (v/v) Dubai], which were utilized as the sole carbon sources, were added to a suspension of the soil mixture through air flow by evaporation $(3 \mathrm{l} / \mathrm{min})$, as shown in Fig. 1. The enrichment culture $(100 \mu \mathrm{l})$, cultivated for more than 6 months, was spread onto agar plates of an inorganic basal medium (IBM) that contained $0.5 \mathrm{~g} / 1 \mathrm{NH}_{4} \mathrm{Cl}, 0.5 \mathrm{~g} / \mathrm{l}\left(\mathrm{NH}_{4}\right)_{2} \mathrm{SO}_{4}$, $0.5 \mathrm{~g} / 1 \mathrm{Na}_{2} \mathrm{SO}_{4}, 0.1 \mathrm{~g} / 1 \mathrm{MgSO}_{4}, 25 \mathrm{mM}$ phosphate buffer (pH 7.0), $100 \mathrm{mg} / \mathrm{l}$ of individual ROCs, and $20 \mathrm{~g} / \mathrm{l}$ of agar. The ROCs were sterilized via filtration with membrane filters (PVDF, $0.22 \mu \mathrm{m}$ pores, Whatman) and added separately to the IBM after autoclaving. The agar plates were incubated for $48 \mathrm{~h}$ at $30^{\circ} \mathrm{C}$ under normal atmospheric conditions.

\section{Identification of ROC-Degrading Bacteria}

Chromosomal DNA was extracted directly from the bacteria selected from the IBM agar plates. 16S Ribosomal DNA was amplified via direct PCR, using the chromosomal DNA template, and 16S rDNA specific universal primers (forward 5'-GAGTTGGATCC- TGGCTCAG3'; reverse 5'-AAGGAGGGGATCCAGCC-3'). The PCR reaction mixture $(50 \mu \mathrm{l})$ consisted of $2.5 \mathrm{U}$ of $\mathrm{Taq}$ polymerase, $250 \mu \mathrm{M}$ each of dNTP, $10 \mathrm{mM}$ Tris- $\mathrm{HCl}$ (pH 9.0), $40 \mathrm{mM} \mathrm{KCl,} 100 \mathrm{ng}$ of template, $50 \mathrm{pM}$ primer, and $1.5 \mathrm{mM} \mathrm{MgCl}_{2}$. Amplification was conducted for 30 cycles of $1 \mathrm{~min}$ at $95^{\circ} \mathrm{C}, 1 \mathrm{~min}$ of annealing at $55^{\circ} \mathrm{C}$, and $2 \mathrm{~min}$ of extension at $72^{\circ} \mathrm{C}$, using a PCR machine (T Gradient model; Biometera, Germany). Bacterial identity was determined on the basis of $16 \mathrm{~S}$ rDNA sequence homology according to the GenBank database system.

\section{ROC Degradation Efficiency}

Each $48 \mathrm{~h}$ cultivated bacterial species, in $100 \mathrm{ml}$ of IBM broth containing an individual ROC, was harvested aseptically via $30 \mathrm{~min}$ of centrifugation at $5,000 \times g$ at $4^{\circ} \mathrm{C}$ and then dissolved in $10 \mathrm{ml}$ of fresh IBM broth, and was subsequently inoculated into $1,000 \mathrm{ml}$ of IBM broth containing $100 \mathrm{mg} / \mathrm{l}$ of the individual ROC. Individual bacterial species were separately cultivated in order to estimate the degradation activity of each bacterial species at $30^{\circ} \mathrm{C}$ in a rotary shaker $(120 \mathrm{rmp}$ ) for 3 days. Bacterial cells were removed from cultures via $40 \mathrm{~min}$ of centrifugation at $5,000 \times g$ and $4^{\circ} \mathrm{C}$, and the supernatant was utilized for ROC analysis.

\section{Simulation of Wastewater Treatment by Mixed Culture}

Each individual bacterial culture was concentrated 10-fold through 40 min of centrifugation at $5,000 \times g$ and at $4^{\circ} \mathrm{C}$, and was mixed together in equal volumes. Fifty $\mathrm{ml}$ of the concentrated bacterial mixtures was inoculated into conventional bioreactors and 


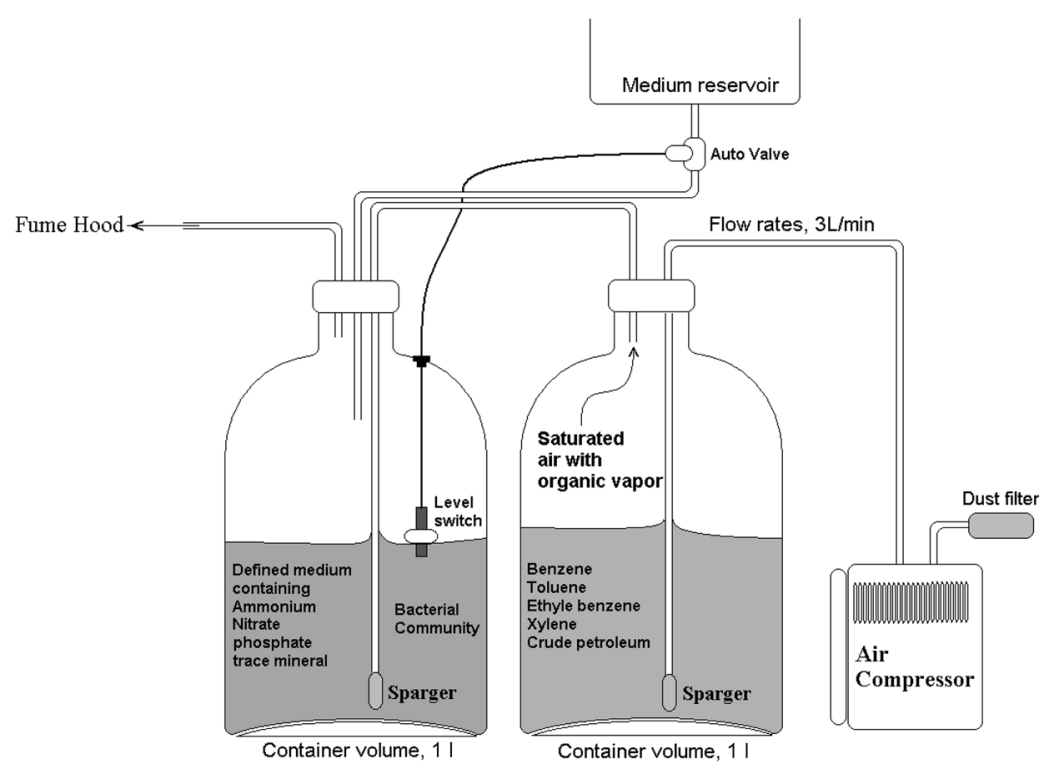

Fig. 1. Bioreactor for the enrichment of a bacterial community capable of degrading organic compounds originating from petroleum or artificially synthesized xenobiotics.

Various organic vapors can be transferred via air flow through the pipeline from the compressor to the bacterial cultures. A one-tenth concentration of fresh medium balanced with evaporated volume was automatically refilled.

electrochemical bioreactors containing $1,000 \mathrm{ml}$ of wastewater A or wastewater B. Both the conventional and the electrochemical bioreactors were cultivated in a rotary shaker for 12 days at $30^{\circ} \mathrm{C}$ and $120 \mathrm{rpm}$. One hundred $\mathrm{ml}$ of culture was sampled to analyze ROC degradation efficiency and bacterial community diversity at 3day intervals. Bacterial cells were separated from the culture sample via $40 \mathrm{~min}$ of centrifugation at $5,000 \times g$ and $4^{\circ} \mathrm{C}$. The supernatants were utilized for ROC analysis and the bacterial precipitants were used for community analysis. Chromosomal DNA was extracted directly from the bacterial precipitant, which was used as the template for $16 \mathrm{~S}$ rDNA amplification.

\section{Electrochemical Bioreactor}

An electrochemical bioreactor was used to estimate the effects of electrochemical reduction reactions on the bacterial degradation of the ROCs and bacterial diversity. As shown in Fig. 2, bacterial cells were cultivated in a modified graphite felt cathode with neutral red (NR) in order to induce the conversion of the electrochemical reduction reaction into biochemical reducing power (NADH). A porous carbon anode, modified with a ceramic membrane and cellulose acetate film, was employed as a counter-electrode to induce the electrolysis of $\mathrm{H}_{2} \mathrm{O}$ that was permeated from the bacterial culture to the porous carbon anode through the cellulose acetate film and ceramic membrane. The cellulose acetate film is a semipermeable membrane that permits water to be diffused selectively from the bacterial culture to the porous carbon anode. The ceramic membrane functions as a barrier to prevent direct contact between bacterial cells and the porous carbon anode. A power supply functions as an electron-driving force to transfer electrons from anode $(+)$ to cathode (-). The NR immobilized in graphite felt mediates electron transfers from the electrode to the bacterial cells, by which $\mathrm{NAD}^{+}$ can be reduced to NADH for the bacterial metabolism [20,37]. The electric potential charged to the NR-cathode was adjusted to -3 volts, by which $9 \pm 0.6 \mathrm{~mA}$ of current was generated. Current generation indicates that electrons were moved from anode to cathode through a coupling redox reaction between the cathode and anode.

\section{Analysis of Living Bacterial Strains}

Bacterial cultures sampled from the conventional and the electrochemical bioreactors were spread on IBM agar plates containing $2 \times$ diluted wastewater $\mathrm{B}$, at 3 -day intervals, for 12 days. The living bacterial species in the bioreactors, during a maximal 12 days of cultivation, may have grown selectively on the agar plates. Chromosomal DNA was extracted directly from all bacterial colonies grown on agar plates, and used as template for $16 \mathrm{~S}$ rDNA amplification.

\section{Thermal Gradient Gel Electrophoresis}

The 16S rDNA amplified from chromosomal DNA was employed as a template for the preparation of the TGGE sample (16S rDNA variable region). A variable region of $16 \mathrm{~S}$ rDNA was amplified with a forward primer [(eubacteria, V3 region) 341f 5'-CCTACGGGAGGCAGCAG$3^{\prime}$ ] and a reverse primer [(universal, V3 region) 518r 5'-ATTACCGC GGCTGCTGG-3']. A GC (5-CGCCCGCCGCGCGCGGCGGGCG GGGCGGGGGCACGGGGGGCCTACGGGAGGCAGCAG-3') was attached to the 5' end of the GC341f primer [27]. The procedures for PCR and DNA sequencing were identical to the 16S rDNA amplification conditions, with the exception of an annealing temperature of $53^{\circ} \mathrm{C}$. The TGGE system (Bio-Rad, Dcode, Universal Mutation Detection System, U.S.A.) was operated in accordance with the manufacturer's specifications. Aliquots $(35 \mu \mathrm{l})$ of the PCR products were electrophoresed in gels containing $8 \%$ acrylamide, $8 \mathrm{M}$ urea, and $20 \%$ formamide with a $1.5 \times$ TAE buffer system, at a constant voltage of $100 \mathrm{~V}$ for $12.5 \mathrm{~h}$, and then at $40 \mathrm{~V}$ for $0.5 \mathrm{~h}$, applying a thermal gradient of $39-52^{\circ} \mathrm{C}$. Prior to electrophoresis, the gel was equilibrated to the temperature gradient for 30-45 $\mathrm{min}$. 

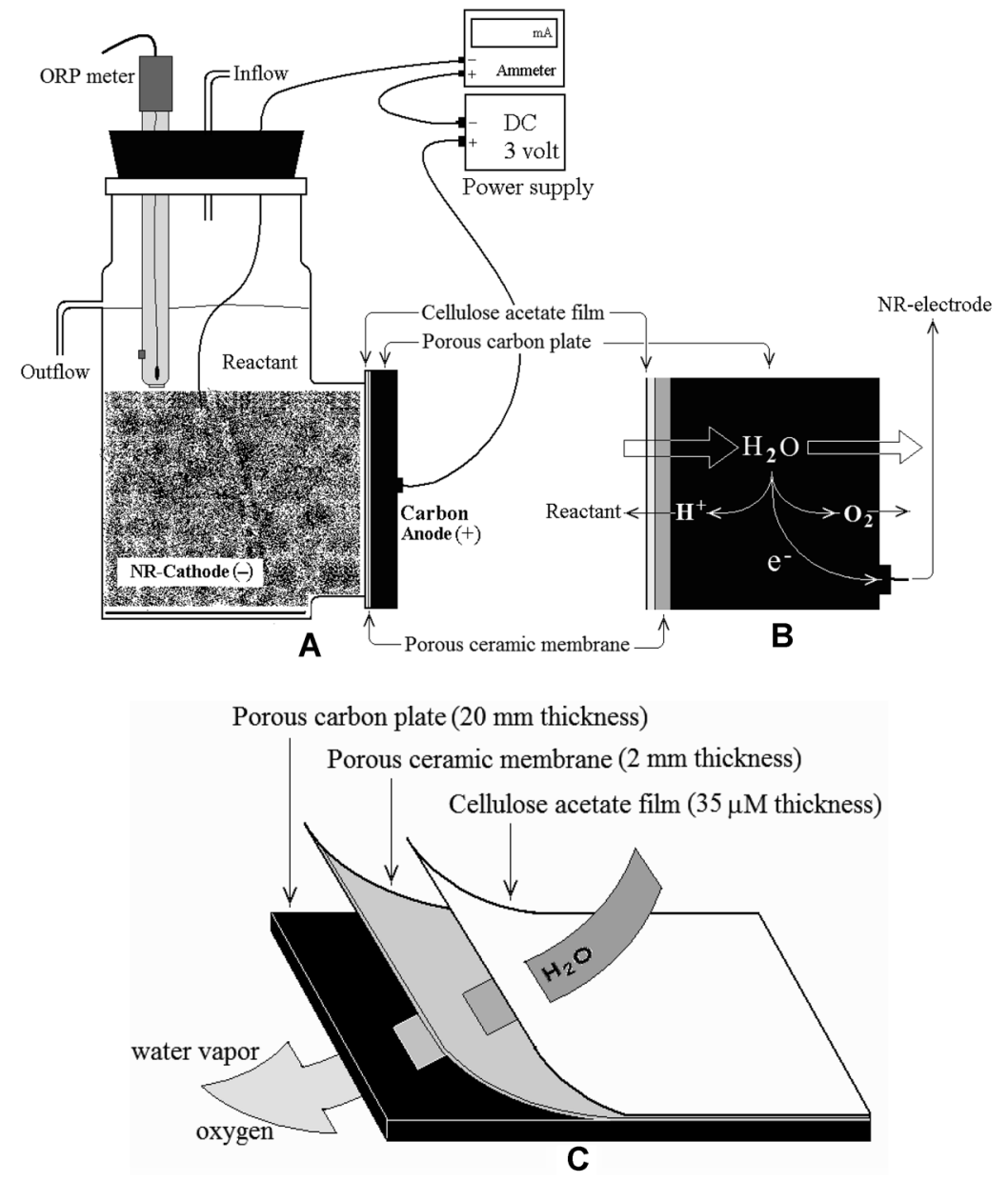

Fig. 2. Schematic structure of an electrochemical bioreactor (A), the operating mechanism (B), and counter-electrode (C).

The modified graphite felt electrode with neutral red (NR-electrode) functions as a solid electron mediator by which NADH in bacterial cytoplasm is electrochemically regenerated. The NR-electrode functions as the cathode $(-)$, and the counter-electrode functions as the anode $(+)$.

\section{Amplification and Identification of TGGE Band}

DNA was extracted separately from each TGGE band and purified with a DNA gel purification kit (Accuprep, Bioneer, Korea). The purified DNA was then amplified with the same primers and procedures used for TGGE sample preparation, in which the GC clamp was not attached to the forward primer. The species-specific identity of the amplified variable $16 \mathrm{~S}$ rDNA was determined on the basis of sequence homology, according to the GenBank database system.

\section{Analysis}

DGMME, DGMEE, NMP, and sulfolane were quantitatively and qualitatively analyzed via GC-MS with modified procedures adapted from the technique developed by Shin and Jung [39]. The diluted bacterial culture $(100 \mathrm{ml})$ containing an individual ROC, or mixed ROCs, was placed in a 250-ml separating funnel. Approximately $30 \mathrm{~g}$ of $\mathrm{NaCl}$ and $100 \mu \mathrm{l}$ of an ethylene glycol butyl ether internal standard solution $(1,000 \mathrm{mg} / \mathrm{l})$ were added to this mixture, and the samples were extracted with $20 \mathrm{ml}$ of methylene chloride via $20 \mathrm{~min}$ of mechanical shaking. The solvent layer was then recovered in a flask. Then, $1,000 \mu \mathrm{l}$ of the solvent phase was transferred to a GC vial. At the appropriate times, a $1 \mu \mathrm{l}$ sample of the solution was analyzed via GC. GC-MS analysis was conducted with a PerkinElmer Clarus 600 gas chromatograph (GC) interfaced with a mass spectrometer detector (PerkinElmer Clarus 600T mass spectrometer). GC separation was conducted with an Agilent DB-WAXETR capillary column ( $30 \mathrm{~m}$ by $0.32 \mathrm{~mm}$; film thickness, $1 \mu \mathrm{m}$ ) using helium as the carrier gas (flow rate, $1.0 \mathrm{ml} / \mathrm{min}$ ). The following $\mathrm{GC}$ temperature program was used: injector temperature, $250^{\circ} \mathrm{C}$; initial oven temperature, $80^{\circ} \mathrm{C}$; rate of temperature increase, $10^{\circ} \mathrm{C} / \mathrm{min}$ up to $250^{\circ} \mathrm{C}$; holding time, $2 \mathrm{~min}$. The samples were injected into a splitless injection mode. The injector was switched to split mode 2 min after the sample was injected.

High-performance liquid chromatography (HPLC; HP1200, Agilent, U.S.A.), coupled with ESI-ion trap MS, was adopted for the analysis of TEG and APOL. The HPLC apparatus consisted of an Rx-SIL column $(3 \times 50 \mathrm{~mm}, 1.8 \mu \mathrm{m}$; Agilent, U.S.A. $)$, connected to an LXQ ion trap mass spectrometer (Thermo Scientific, U.S.A.), through its ESI interface. A small aliquot of the filtered bacterial culture $(10 \mu \mathrm{l})$ was injected into the chromatographic system. The mobile phase consisted of methanol/ $\mathrm{H}_{2} \mathrm{O} /$ formic acid $[80 / 20 / 0.05(\mathrm{v} /$ $\mathrm{v} / \mathrm{v})$ ] with a flow rate of $0.1 \mathrm{ml} / \mathrm{min}$. The LXQ spectrometer, which 
was controlled completely by Xcalibur software (Thermo Scientific, U.S.A.), was operated in the positive-ion mode; selected ion monitoring (for an $\mathrm{m} / z$ of 195.0 and 76.0, respectively, corresponding to the charged ion $[\mathrm{M}+\mathrm{H}]^{+}$of TEG and APOL) modes were recorded for each sample.

\section{RESULTS}

Isolation and Identification of ROC-Degrading Bacteria Acinetobacter sp., Pseudomonas sp.3, Paracoccus sp., Pseudomonas sp.5, and Cupriavidus sp. were ultimately selected from bacterial colonies grown on the IBM agar plates containing each individual ROC, and were identified based on 16S rDNA sequence homology. The isolates were registered in the GenBank database system, from which accession numbers were obtained as follows: FJ877153 for Acinetobacter sp. SMIC-1, FJ877154 for Pseudomonas sp. SMIC-3, FJ877155 for Paracoccus sp.
SMIC-4, FJ877156 for Pseudomonas sp. SMIC-5, and FJ877152 for Cupriavidus sp. SMIC-2.

\section{ROC Degradation Activity of Isolates}

In order to determine the mineralization activity of the isolates for each individual ROC, 5 bacterial species were cultivated separately in an IBM broth containing $100 \mathrm{mg} / \mathrm{l}$ of DGMME, TEG, DGMEE, APOL, NMP, or sulfolane. As is shown in Table 1, Acinetobacter sp. degraded more than $99 \mathrm{mg} / 1$ of DGMME, DGMEE, and NMP, but less than $10 \mathrm{mg} / \mathrm{l}$ of APOL and sulfolane, in 3 days. Cupriavidus sp. and Pseudomonas sp. degraded more than $95 \mathrm{mg} / \mathrm{l}$ of APOL and $20 \mathrm{mg} / 1$ of sulfolane in 3 days. Paracoccus sp. degraded approximately $43 \mathrm{mg} / \mathrm{l}$ of sulfolane and $59 \mathrm{mg} / \mathrm{l}$ of APOL in 3 days. However, no bacterial species degraded more than $50 \mathrm{mg} / \mathrm{l}$ of sulfolane in 3 days. This implies that more than 3 days may be required for the effective degradation of sulfolane.

Table 1. Chemical species and structure of ROCs contained in wastewater, which was catabolized by bacterial species isolated from an enrichment culture.

\begin{tabular}{|c|c|c|}
\hline Chemicals & Structures & $\begin{array}{l}\text { Chemical-degrading bacterial sp. } \\
\text { (Maximal efficiency, mg/l) }\end{array}$ \\
\hline $\begin{array}{l}\text { Diethyleneglycol } \\
\text { monomethylether } \\
\text { (DGMME) }\end{array}$ & & $\begin{array}{l}\text { Acinetobacter sp. }(100 \pm 0) \\
\text { Cupriavidus } \mathrm{sp} .(99.3 \pm 1.2) \\
\text { Paracoccus } \mathrm{sp} .(98.3 \pm 0.6) \\
\text { Pseudomonas sp. } 3(37 \pm 1.7) \\
\text { Pseudomonas sp.5 }(32 \pm 1.0)\end{array}$ \\
\hline $\begin{array}{l}\text { Tetraethyleneglycol } \\
\text { (TEG) }\end{array}$ & & $\begin{array}{l}\text { Acinetobacter sp. }(77.9 \pm 0.1) \\
\text { Cupriavidus sp. }(93.5 \pm 1.7) \\
\text { Pseudomonas sp.3 }(9.3 \pm 1.6) \\
\text { Pseudomonas sp. } 5(46.6 \pm 0.9) \\
\text { Paracoccus sp. }(0.3 \pm 0.2)\end{array}$ \\
\hline $\begin{array}{l}\text { Diethyleneglycol } \\
\text { monoethylether } \\
\text { (DGMEE) }\end{array}$ & & $\begin{array}{l}\text { Acinetobacter sp. }(100 \pm 0) \\
\text { Cupriavidus sp. }(99.3 \pm 1.2) \\
\text { Paracoccus sp. }(98.3 \pm 1.0) \\
\text { Pseudomonas sp. } 3(33 \pm 1.7) \\
\text { Pseudomonas sp.5 }(36 \pm 1.0)\end{array}$ \\
\hline $\begin{array}{l}\text { 1-Amino-2-propanol } \\
\text { (APOL) }\end{array}$ & & 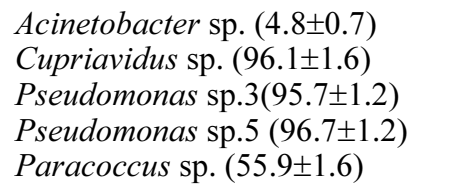 \\
\hline $\begin{array}{l}\text { 1-Methyl-2-pyrrolidinone } \\
\text { (NMP) }\end{array}$ & & $\begin{array}{l}\text { Acinetobacter sp. }(99.9 \pm 0.1) \\
\text { Cupriavidus sp. }(99.5 \pm 0.5) \\
\text { Pseudomonas sp.3 }(99.8 \pm 0.3) \\
\text { Pseudomonas sp.5 }(11 \pm 1.0) \\
\text { Paracoccus sp. }(13 \pm 1.0)\end{array}$ \\
\hline $\begin{array}{l}\text { Tetrahydrothiophene1,1-dioxide } \\
\text { (sulfolane) }\end{array}$ & & $\begin{array}{l}\text { Acinetobacter sp. }(9.9 \pm 0.1) \\
\text { Cupriavidus sp. }(20 \pm 1.0) \\
\text { Pseudomonas sp.3 }(20 \pm 1.8) \\
\text { Pseudomonas sp.5 }(21 \pm 1.0) \\
\text { Paracoccus sp. }(43 \pm 2.0)\end{array}$ \\
\hline
\end{tabular}

Numbers in parentheses indicate the maximal concentration of chemical species degraded biologically by an individual bacterial species for 3 days. 
Table 2. Degradation efficiency of wastewaters A and B by mixed culture of 5 bacterial species, Acinetobacter sp., Cupriavidus sp., Paracoccus sp., Pseudomonas sp.3, and Pseudomonas sp.5, during 12 days of incubation.

\begin{tabular}{|c|c|c|c|c|c|c|c|c|}
\hline \multirow[t]{2}{*}{ Chemicals } & \multicolumn{4}{|c|}{$\begin{array}{c}\text { Conventional } \\
\text { bioreactor (mg/l) }\end{array}$} & \multicolumn{4}{|c|}{$\begin{array}{l}\text { Electrochemical } \\
\text { bioreactor }(\mathrm{mg} / \mathrm{l})\end{array}$} \\
\hline & 0 & 3 & 6 & 9 & 0 & 3 & 6 & 9 \\
\hline $\begin{array}{l}\text { Diethyleneglycol } \\
\text { monomethylether } \\
\text { (DGMME) }\end{array}$ & $1,250 \pm 7.5$ & $42 \pm 2$ & $<2$ & $<2$ & $1,250 \pm 8.3$ & $41 \pm 1.7$ & $<2$ & $<2$ \\
\hline $\begin{array}{l}\text { Tetraethyleneglycol } \\
\text { (TEG) }\end{array}$ & $36 \pm 1.1$ & $<2$ & $<2$ & $<2$ & $36 \pm 1.2$ & $<2$ & $<2$ & $<2$ \\
\hline $\begin{array}{l}\text { Diethyleneglycol } \\
\text { monoethylether } \\
\text { (DGMEE) }\end{array}$ & $166 \pm 6.2$ & $<2$ & $<2$ & $<2$ & $166 \pm 6.7$ & $<2$ & $<2$ & $<2$ \\
\hline $\begin{array}{l}\text { 1-Amino-2-propanol } \\
\text { (APOL) }\end{array}$ & $75 \pm 2.1$ & $6 \pm 0.8$ & $<2$ & $<2$ & $75 \pm 3.1$ & $7 \pm 0.5$ & $<2$ & $<2$ \\
\hline $\begin{array}{l}\text { 1-Methyl-2-pyrrolidinone } \\
\text { (NMP) }\end{array}$ & $532 \pm 18.2$ & $<2$ & $<2$ & $<2$ & $532 \pm 21.8$ & $<2$ & $<2$ & $<2$ \\
\hline $\begin{array}{l}\text { Tetrahydrothiophene } \\
\text { 1,1-dioxide } \\
\text { (sulfolane) }\end{array}$ & $238 \pm 12.2$ & $201 \pm 13.0$ & $126 \pm 7.3$ & $<2$ & $238 \pm 12.8$ & $151 \pm 11.3$ & $<2$ & $<2$ \\
\hline
\end{tabular}

Minimal detection value of GCMS is $2 \mathrm{mg} / \mathrm{l}$ or more.

Initial concentrations of ROCs were determined just prior to inoculation of the bacterial cells into the bioreactors.

Simulation of Wastewater Treatment by Mixed Culture The degradation efficiencies of wastewater A containing DGMME, or wastewater B containing other mixtures of ROCs prepared by mixed cultures of 5 bacterial species, were qualitatively and quantitatively analyzed. As shown in Table 2, more than 1,200 mg/l of DGMME, $34 \mathrm{mg} / \mathrm{l}$ of
TEG, $164 \mathrm{mg} / \mathrm{l}$ of DGMEE, $68 \mathrm{mg} / \mathrm{l}$ of APOL, and $530 \mathrm{mg} / \mathrm{l}$ of NMP with a mixed culture of the five bacterial species were placed in both the conventional and electrochemical bioreactors for 3 days of incubation time. At least 9 days and 6 days were required for the effective degradation of sulfolane in the conventional and electrochemical bioreactors,

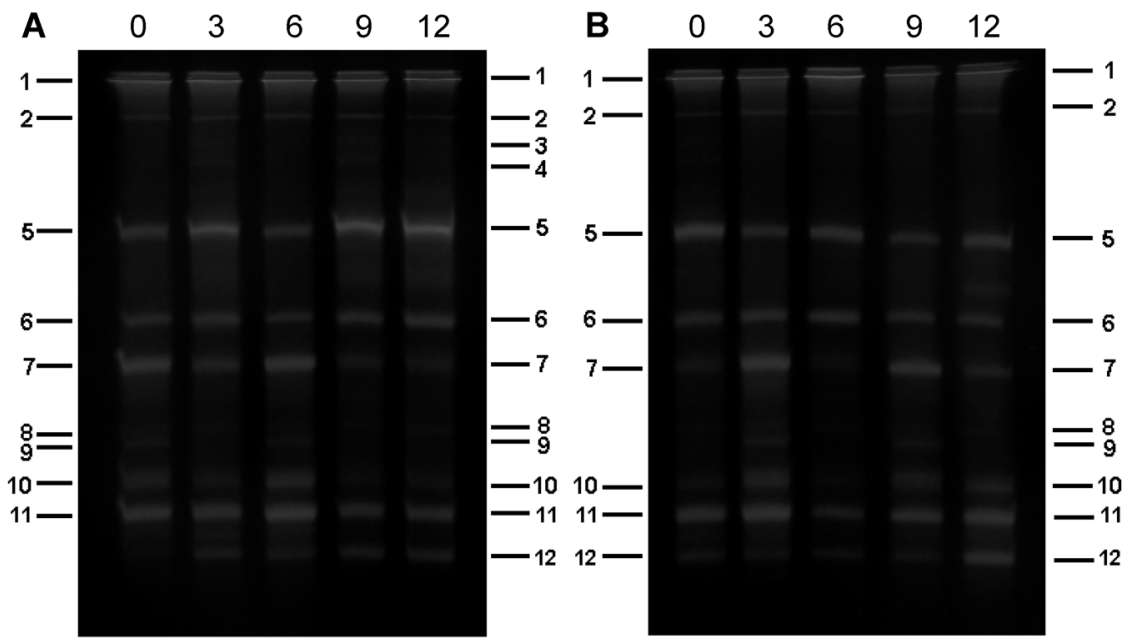

Fig. 3. Time-course diversity of the bacterial community grown in wastewater A containing DGMME (plate A) and wastewater B containing TEG, DGMEE, APOL, NMP and sulfolane (plate B) in the conventional bioreactor.

Bacterial cultures were sampled from each bioreactor immediately after inoculation ( 0 day $)$ and on the $3^{\text {rd }}, 6^{\text {th }}, 9^{\text {th }}$, and $12^{\text {th }}$ days of incubation time. The numbered DNA band was identified on the basis of sequence homology, as follows: 1. Acinetobacter sp.; 2. Pseudomonas sp.; 3. Pseudomonas sp.; 4. Pseudomonas sp.; 5. Pseudomonas sp.; 6. Alkaligenese sp.; 7. Acinetobacter sp.; 8. Paracoccus sp.; 9. Paracoccus sp.; 10. Cupriavidus sp.; 11. Alkaligenes sp.; 12. Paracoccus sp. 


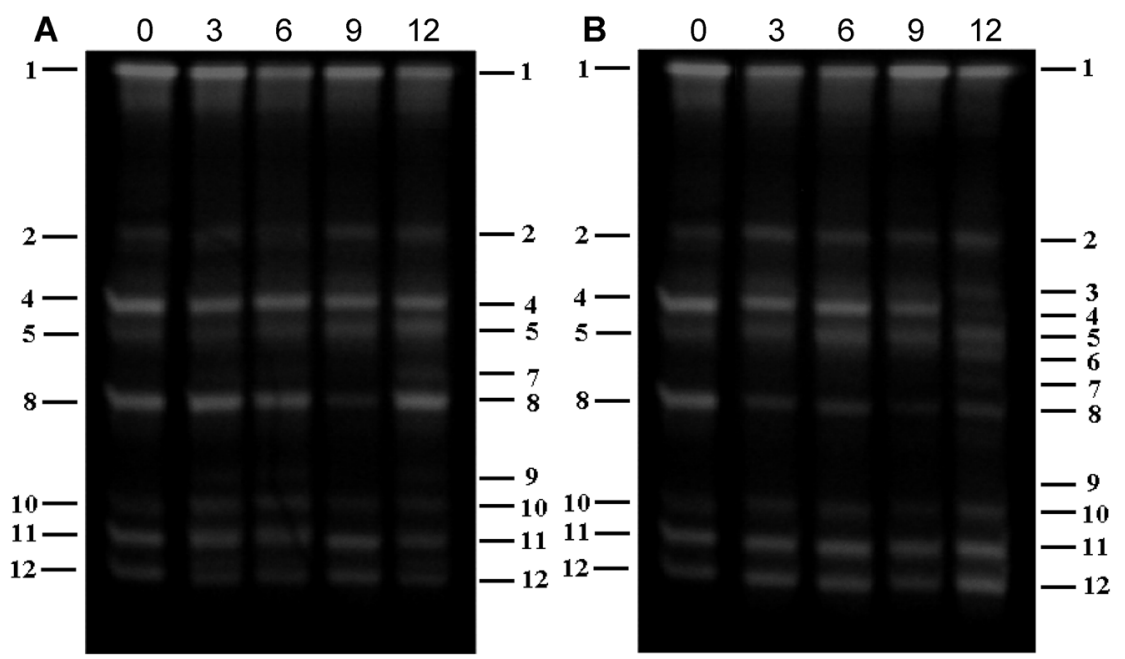

Fig. 4. Time-course diversity of the bacterial community cultivated in wastewater A containing DGMME (plate A) and wastewater B containing TEG, DGMEE, APOL, NMP, and sulfolane (plate B) in an electrochemical bioreactor.

Bacterial cultures were sampled from each bioreactor immediately after inoculation $(0$ day $)$ and on the $3^{\text {rd }}, 6^{\text {th }}, 9^{\text {th }}$, and $12^{\text {th }}$ days of incubation time. The numbered DNA band was identified on the basis of sequence homology as follows: 1. Acinetobacter sp.; 2. Acinetobacter sp.; 3. Paracoccus sp.; 4. Pseudomonas sp.; 5. Acinetobacter sp.; 6. Acinetobacter sp.; 7. Acinetobacter sp.; 8. Acinetobacter sp.; 9. Paracoccus sp.; 10. Cupriavidus sp.; 11. Alkaligenes sp.; 12. Paracoccus sp.

respectively. Six or 9 days of long-term incubation may be a limiting factor in the bacterial treatment of wastewater containing ROCs, as some bacterial species may lose their physiological properties through starvation under substrateexhausting conditions [26, 42, 45].

\section{Bacterial Community Diversity During Wastewater Treatment}

TGGE patterns for the bacterial communities, cultivated in both the conventional and the electrochemical bioreactors, did not vary significantly with elapsed incubation time, as is shown in Fig. 3 and 4. All of the partial $16 \mathrm{~S}$ rDNA extracted from the TGGE bands were identified with five bacterial species that were inoculated into the bioreactors from the inception of the experiment. However, amongst the bacterial communities cultivated in the bioreactors during the 12 days of incubation, the TGGE pattern did not verify that all DNA bands on the TGGE gel were extracted from the living strains.

\section{Analysis of Living Strains During Wastewater Treatment} The TGGE patterns for the bacterial colonies grown on the IBM agar plates differed significantly from those (Fig. 3 and 4) noted for the bacterial communities cultivated in the bioreactors, as shown in Fig. 5. Some TGGE bands were found to have decreased, or disappeared, as the incubation time passed. Based on the TGGE patterns of $16 \mathrm{~S}$ rDNA, Pseudomonas sp. (band number 7), Cupriavidus sp. (band number 10), Alkaligenes sp. (band number 11), and Paracoccus sp. (band number 12) were shown to have decreased on the $9^{\text {th }}$ and $12^{\text {th }}$ days in the conventional bioreactor, but not in the electrochemical bioreactor, whereas Acinetobacter sp. (band number 5) showed a reduction on the $9^{\text {th }}$ and $12^{\text {th }}$
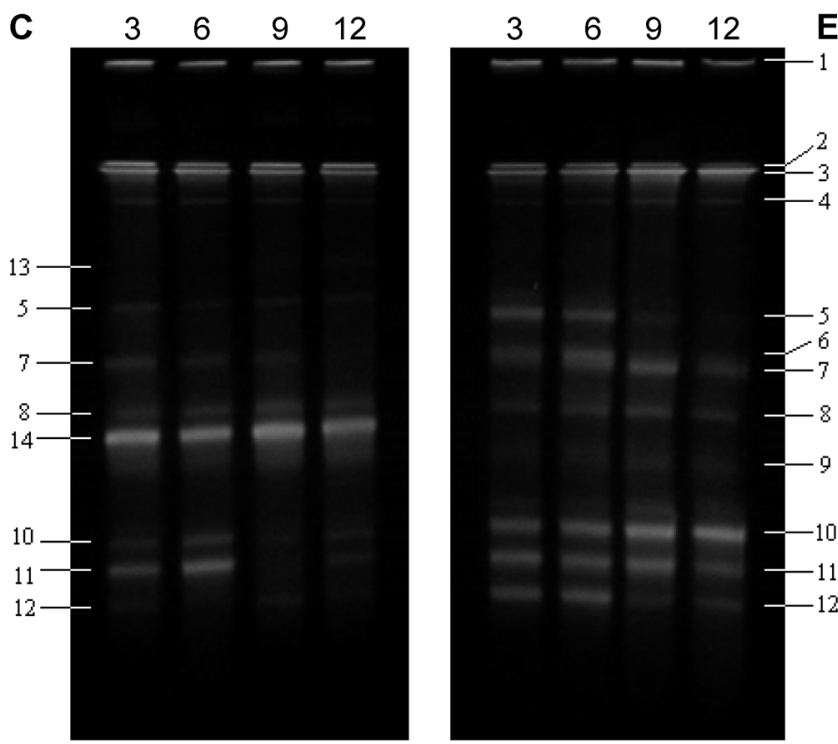

Fig. 5. Time-course diversity of the biochemically active bacterial community cultivated in wastewater B containing TEG, DGMEE, APOL, NMP, and sulfolane in the conventional (plate C) and electrochemical (plate E) bioreactors for 12 days.

Bacterial cultures sampled aseptically from each bioreactor were spread on IBM agar plates containing 6 ROCs on the $3^{\text {rd }}, 6^{\text {th }}, 9^{\text {th }}$, and $12^{\text {th }}$ days of incubation time. The numbered DNA band was identified based on the following sequence homology: 1-3. Acinetobacter sp.; 4. Uncultured; 5. Acinetobacter sp.; 6. Acinetobacter sp.; 7. Pseudomonas sp.; 8. Pseudomonas sp.; 9. Paracoccus sp.; 10. Cupriavidus sp.; 11. Alkaligenes sp.; 12. Paracoccus sp.; 13. Acinetobacter sp.; 14. Acinetobacter sp. 
days in the electrochemical bioreactor. In particular, Cupriavidus sp. (band number 10), Alkaligenes sp. (band number 11), and Paracoccus sp. (band number 12) proved unstable in the conventional bioreactor during cultivation, which was significantly different from the results seen in the electrochemical bioreactor. Generally, half of the TGGE bands were identified as Acinetobacter sp., which is very similar to the case of the TGGE pattern for DNA extracted directly from the bacterial communities cultivated in the bioreactors.

\section{Discussion}

DGMME, TEG, DGMEE, APOL, NMP, and sulfolane are ROCs that are typically contained in wastewater generated by an electronics company. The bacterial cultures isolated from three different sewage treatment reactors, and soil bacteria isolated from contaminated soils with petroleum, did not grow on IBM agar media containing the ROCs as sole carbon sources. However, the bacterial community isolated from the enrichment culture (Fig. 1) grew actively on the IBM agar plates (Table 1). Six months were permitted for the natural bacterial communities to adapt upon exposure to benzene, toluene, ethylbenzene, xylene, thiophenes, and crude petroleum. This may be sufficient to induce the bacterial community to degrade ROCs that are structurally different from the xenobiotics utilized for adaptation $[9,28]$. However, the optimal enrichment period for the induction of a bacterial community to fully degrade target ROCs may be difficult to estimate, as adaptation involves the de novo synthesis of enzymes, the growth and proliferation of degradative populations, intra- and interspecific transfers of genetic information, or molecular alterations of existing enzyme systems [29, 38].

DGMME, DGMEE, and TEG are structural isomers, whereas APOL, NMP, and sulfolane differ structurally from one another. Generally, the ROCs contained in the electronic company's wastewater were almost completely degraded by at least three strains. However, the degradation pattern and efficiency of the ROCs by the 5 bacterial strains did not appear to be attributable to structural properties (Table 1). The maximal degradation efficiency of DGMME, DGMEE, TEG, APOL, and NMP, by a single bacterial strain, was greater than $93 \%$, whereas the maximum degradation efficiency of sulfolane, by a single strain, was less than $43 \%$. This latter result may be attributable to the disulfide structure of sulfolane. No metabolite, or bypass product, was detected during GC-MS and LC-MC analyses. This shows that the ROCs may have completely mineralized into inorganic compounds, such as $\mathrm{CO}_{2}, \mathrm{NO}_{3}{ }^{-}$, $\mathrm{SO}_{3}{ }^{2-}$, and $\mathrm{SO}_{4}{ }^{2-}$, under aerobic conditions. Greene and Federak [17] demonstrated experimentally that mixed cultures of aerobic sulfolane-degrading bacteria mineralized sulfolane to $\mathrm{CO}_{2}$ and $\mathrm{SO}_{4}{ }^{2-}$.

The low degradation efficiency of sulfolane represents an issue that may be solved by an extension of the treatment time, though not by a mixed culture of the five bacterial strains. Greene et al. [16] previously reported that $100 \mathrm{mg} / \mathrm{l}$ of sulfolane was degraded completely by an aerobic bacterial community in 4.2 days, and $100 \mathrm{mg} / \mathrm{l}$ of sulfolane was degraded to $\mathrm{H}_{2} \mathrm{~S}$ and $\mathrm{CO}_{2}$ by aquifer sediment microorganisms, under anaerobic nitrate conditions, in 6.25 days. Sulfolane may be a typical ROC, based on its biodegradation efficiency (Table 2) and other research data. Aerobic treatment techniques are superior to anaerobic techniques for the biodegradation of sulfolane, considering the treatment time and $\mathrm{H}_{2} \mathrm{~S}$ generation characteristics. $\mathrm{H}_{2} \mathrm{~S}$, which is highly toxic to all organisms, is a metabolite generated by sulfate-reducing bacteria under strict anaerobic environmental conditions. Waste sediments generated from industry can frequently contain a large quantity of organic matter, which may be a primary cause of $\mathrm{H}_{2} \mathrm{~S}$ formation $[6,18]$.

The sulfone (sulfur dioxide) moiety of benzothiophene sulfone $\left(\mathrm{BTSO}_{2}\right)$, which is structurally similar to that of sufolane, is bacteriologically oxidized into $\mathrm{SO}_{3}^{2-}$ by Rhodococcus sp. [25]. This has been proposed as a model by which the degradation pathway of sulfolane might be determined. The sulfur dioxide moiety of sulfolane may be oxidized to $\mathrm{SO}_{3}{ }^{2-}$, and the hydrocarbon moiety may be oxidized to alcohol, via biochemical oxygenation in combination with NADH oxidation $[21,35]$. Biochemical oxygenation is activated at a high balance of NADH/ $\mathrm{NAD}^{+}$, which can be maintained physiologically by the electrochemical regeneration of NADH $[23,36]$. Accordingly, the electrochemical reduction reaction is another means of reducing the treatment time of sulfolane-containing wastewater. The electrochemical bioreactor may be a useful system, being a low electrical-energy-consuming device that can induce the regeneration of NADH in coupling with bacterial metabolism. The extinction of some bacterial strains, such as Pseudomonas sp., Cupriavidus sp., Alkaligenes sp., and Paracoccus sp. (Fig. 5C), may be caused by the exhaustion of specific ROCs in conventional bioreactors, whereas the preservation of most bacterial strains in the electrochemical bioreactor during the full 12 days of incubation (Fig. 5E) may be induced by a high $\mathrm{NADH} / \mathrm{NAD}^{+}$ratio. Differences in TGGE patterns between DNA extracted from bacterial colonies grown on agar plates (Fig. 5), and DNA extracted directly from cultures in the bioreactors (Fig. 3 and 4), indicate that specific bacterial strains may lose their physiological activity without structural loss.

The biological degradation of chemically complex wastewater is somewhat limited, as a bacterial species may 
not prove capable of adaptation to all chemical species [3]. The bacterial absorption, degradation, and catabolism of chemical species can vary, depending on chemical structures and elemental compositions [14,19]. Multiple bacterial species with syntrophic relationships may be a solution for the complete degradation of all kinds of chemical species, and a multistage bioreactor containing different bacterial species may also be a valid solution [24, 32]. However, it is difficult to induce the spontaneous composition of a syntrophically related bacterial consortium in a bioreactor, as a specific bacterial species adapted to a chemical species must be selected artificially from the natural environment, or an enrichment culture. Theoretically, it may be possible to compose, in vitro, an optimal combination of bacterial species for the complete treatment of chemically complex wastewater. However, it would be very difficult to formulate an optimal treatment system in situ.

In conclusion, a specific chemical species (sulfolane) that is slowly degraded via bacterial metabolism may be a limiting factor in determining the treatment efficiency of wastewater containing complex ROCs, and an extension of the treatment time may be a solution to improve treatment efficiency. However, some bacterial species may abrogate their physiological activity as the result of substrate exhaustion. The diversity of a bacterial community is the most important factor in a continuous wastewater treatment reactor. The electrochemical reduction reaction may prove to be a method by which the bacterial community may be maintained and bacterial metabolism may be activated.

\section{REFERENCES}

1. Aamand, J., C. Jorgensen, E. Arvin, and B. K. Jensen. 1989. Microbial adaptation to degradation of hydrocarbons in polluted and unpolluted groundwater. J. Contam. Hydrol. 4: 299-312.

2. Aelion, C. M., C. M. Swindoll, and F. K. Pfaender. 1987. Adaptation to and biodegradation of xenobiotic compounds by microbial communities from a pristine aquifer. Appl. Environ. Microbiol. 53: 2212-2217.

3. Aelion, C. M., D. C. Dobbins, and F. K. Pfaender. 1989. Adaptation of aquifer microbial communities to the biodegradation of xenobiotic compounds: Influence of substrate concentration and preexposure. Appl. Microbiol. Biotechnol. 8: 75-86.

4. Alexander, M. 1981. Biodegradation of chemicals of environmental concern. Science 211: 132-138.

5. Alexander, M. 1985. Biodegradation of organic chemicals. Environ. Sci. Technol. 19: 106-111.

6. Asaoka, S., T. Yamamoto, S. Kondo, and S. Hayakawa. 2009. Removal of hydrogen sulfide using crushed oyster shell from pore water to remediate organically enriched coastal marine sediments. Bioresource Technol. 100: 4127-4132.

7. Bachmann, A., W. de Bruin, J. C. Jumelet, H. H. N. Rijnaarts, and A. J. B. Zehnder. 1988. Aerobic biomineralization of alphahexachlorocyclohexane in contaminated soil. Appl. Environ. Microbiol. 54: 548-554.
8. Barkay, T. and H. Pritchard. 1988. Adaptation of aquatic micriobial communities to pollutant stress. Microbiol. Sci. 5: 165-169.

9. Becker, J. G., G. Berardesco, B. E. Rittmann, and D. A. Stahl. 2006. Effects of endogenous substrates on adaptation of anaerobic microbial communities to 3-chlorobenzoate. Appl. Environ. Microbiol. 72: 449-456.

10. Behki, R. M. and S. U. Khan. 1986. Degradation of atrazine by Pseudomonas: N-dealkylation and dehalogenation of atrazine and its metabolites. J. Agric. Food Chem. 34: 746-749.

11. Chaudhry, G. R. and G. H. Huang. 1988. Degradation of bromacil by a Pseudomonas sp. Appl. Environ. Microbiol. 54: 2203-2207.

12. Cook, A. M., H. Grossenbacher, and R. Hüter. 1983. Isolation and cultivation of microbes with biodegradative potential. Experientia 39: 1101-1198.

13. Dec, J. and J. M. Bollg. 1988. Microbial release and degradation of catechol and chlorophenols bound to synthetic humic acid. Soil Sci. Soc. Am. J. 52: 1366-1371.

14. Fournier, J. C., P. Codaccioni, G. Soulas, and C. Repiquet. 1981. Soil adaptation to 2,4-D degradation in relation to the application rates and the metabolic behavior of the degrading microflora. Chemosphere 10: 977-984.

15. Grady, C. P. L. 1985. Biodegradation: Its measurement and microbiological basis. Biotechnol. Bioeng. 27: 660-674.

16. Greene, E. A., L. M. Gieg, D. L. Coy, and P. M. Fedorak. 1998. Sulfolane biodegradation potential in aquifer sediments at sour natural gas plant sites. Wat. Res. 32: 3680-3688.

17. Greene, E. A. and P. M. Federak. 1998. A differential medium for the isolation and enumeration of sulfolane-degrading bacteria. J. Microbiol. Methods 33: 255-262.

18. Hayes, M. K. and G. T. Tayleor. 2006. Vertical distributions of thiosulfate and sulfite in the Cariaco basin. Limnol. Oceanogr. 51: 280-287.

19. Hwang, H-.M., R. E. Hodson, and D. L. Lewis. 1989. Microbial degradation kinetics of toxic organic chemicals over a wide range of concentrations in natural aquatic systems. Environ. Toxicol. Chem. 8: 65-74.

20. Hwang, T. S., B. K. Na, H. T. Tran, D. H. Ahn, and D. H. Park. 2008. A novel three-compartmented electrochemical bioreactor for enrichment of strict anaerobes based on metabolite production. Biotechnol. Bioprocess Eng. 13: 677-682.

21. Izumi, Y., T. Oshiro, H. Ogino, Y. Hine, and M. Shimao. 1994. Selective desulfurization by Rhodococcus erythropolis D-1. Appl. Environ. Microbiol. 60: 223-226.

22. Jokela, J., J. Pellinen, and M. Salkinoja-Salonen. 1987. Initial steps in the pathway for bacterial degradation of two tetrameric liginin model compounds. Appl. Environ. Microbiol. 53: 26422649.

23. Kang, H. S., B. K. Na, and D. H Park. 2007. Oxidation of butane to butanol coupled to electrochemical redox reaction of $\mathrm{NAD}^{+} / \mathrm{NADH}$. Biotech. Lett. 29: 1277-1280.

24. Katsuyama, C., S. Nakaoka, Y. Takeuchi, K. Tago, M. Hayatsu, and K. Kato. 2009. Complementary cooperation between syntrophic bacteria in pesticide degradation. J. Theor. Biol. 256: 644-654.

25. Kirimura, K., T. Furuya, R. Sato, Y. Ishii, K. Kino, and S. Usami. 2002. Biodesulfurization of naphthothiophene and benzothiophene through selective cleavage of carbon-sulfur 
bonds by Rhodococcus sp. strain WU-K2R. Appl. Environ. Microbiol. 68: 3867-3872.

26. Kurath, G. and R. Y. Morita. 1983. Starvation-survival physiological studies of a marine Pseudomonas sp. Appl. Environ. Microbiol. 45: 1206-1211.

27. Lee, S. J., Y. W. Lee, J. Chung, J. K. Lee, J. Y. Lee, D. Jahng, Y. Cha, and Y. Yu. 2008. Reuse of low concentrated electronic wastewater using selected microbe immobilized cell system. Water Sci. Technol. 57: 1191-1197.

28. Lewis, D. L., H. P. Kollig, and R. E. Hodson. 1986. Nutrient limitation and adaptation of microbial populations to chemicals transformations. Appl. Environ. Microbiol. 55: 2773-2778.

29. Linkfield, T. G., J. M. Suflita, and J. M. Tiedjei. 1989. Characterization of the acclimation period before anaerobic dehalogenation of halobenzoates. Appl. Environ. Microbiol. 55: 2773-2778.

30. Lorenz., M. G., B. W. Aardema, and W. Wackernagel. 1988. Highly efficient genetic transformation of Bacillus subtilis attached to sand grains. J. Gen. Microbiol. 134: 107-112.

31. Madsen, E. L., J. L. Sinclair, and W. C. Ghiorse. 1991. In situ biodegradation: Microbiological patterns in a contaminated aquifer. Science 252: 830-833.

32. Nelson, M. I. and A. Holder. 2009. A fundamental analysis of continuous flow bioreactor models governed by Contois kinetics. II. Reactor cascade. Chem. Eng. J. 149: 406-416.

33. Nishino, S. F. and J. C. Spain. 1993. Cell density-dependent adaptation of Pseudomonas putida to biodegradation of $p$ nitrophenol. Environ. Sci. Technol. 27: 489-494.

34. Ogunseitan, O. A., I. K. Delgado, Y. L. Tsai, and B. H Olson. 1991. Effect of 2-hydroxybenzoate on the maintenance of naphthalene-degrading pseudomonads in seeded and unseeded soil. Appl. Environ. Microbiol. 57: 2873-2879.

35. Omori, T., L. Monna, Y. Saiki, K. Kasuga, and T. Kodama. 1992. Desulfurization of dibenzothiophene by Corynebacterium sp. strain SY1. Appl. Environ. Microbiol. 58: 911-915.

36. Park, D. H. and J. G. Zeikus. 1999. Utilization of electrically reduced neutral red by Acinetobacillus succinogenes: Physiological function of neutral red in membrane-driven fumarate reduction and energy conservation. J. Bacteriol. 181: 2403-2410.

37. Park, D. H., M. Laivenieks, M. V. Guettler, M. K. Jain, and J. G. Zeikus. 1999. Microbial utilization of electrically reduced neutral red as the sole electron donor for growth and metabolite production. Appl. Environ. Microbiol. 66: 2912-2917.

38. Schell, J. A. 1985. Transcriptional control of the nah and sal hydrocarbon degradation operons by the nahr gene product. Gene 36: 301-309.

39. Shin, H. S. and D. G. Jung. 2004. Determination of icing inhibitors (ethylene glycol monomethyl ether and diethylene glycol monomethyl ether) in ground water by gas chromatography-mass spectrometry. Bull. Kor. Chem. Soc. 25: 806-808.

40. Spain, J. C. and P. A. van Veld. 1983. Adaptation of natural microbial communities to degradation of xenobiotic compounds: Effects of concentration, exposure, time, inoculum, and chemical structure. Appl. Environ. Microbiol. 45: 428-435.

41. Swindoll, C. M., C. M. Aelion, and F. K. Pfaender. 1988. Influence of inorganic and organic nutrients on aerobic biodegradation and on the adaptation response of subsurface microbial communities. Appl. Environ. Microbiol. 54: 212-217.

42. Thomsson, E., C. Larsson, E. Albers, A. Nilsson, C. J. Franzén, and L. Gustafsson. 2003. Carbon starvation can induce energy deprivation and loss of fermentativity in Saccharomyces cerevisiae. Appl. Environ. Microbiol. 69: 3251-3257.

43. Van der Meer, J. R., W. Roelofsen, G. Schraa, and A. J. B. Zehner. 1987. Degradation of low concentrations of dichlorobenzenes and 1,2,4-trichlorobenzene by Pseudomonas sp. strain P51 in monstrile soil column. FEMS Microbiol. Ecol. 45: $333-341$.

44. Van der Meer, J. R., W. De Vos, S. Harayama, and A. J. B. Zehnder. 1992. Molecular mechanisms of genetic adaptation to xenobiotic compounds. Microbiol. Rev. 56: 677-694.

45. Wei, X. and W. D. Bauer. 1998. Starvation-induced changes in motility, chemotaxis, and flagellation of Rhizobium meliloti. Appl. Environ. Microbiol. 64: 1708-1714.

46. Wiggins, B. A., S. H. Jones, and M. Alexander. 1987. Explanations for the acclimation period preceding the mineralization of organic chemicals in aquatic environments. Appl. Environ. Microbiol. 53: 791-796.

47. Wilson, J. T., J. F. McNabb, J. W. Cochran, T. H. Wang, M. B. Tomson, and P. B. Bedient. 1985. Influence of microbial adaptation on the fate of organic pollutants in ground water. Environ. Toxicol. Chem. 4: 721-726. 